\title{
Compulsory loyalty? Accountability, citizenship and the BBC
}

Richard Collins*

\section{Introduction}

Throughout the period 2004-2006 UK media policy debates were dominated by consideration of the governance, accountability and role of the BBC in Parliamentary and other enquiries (see, inter alia, BBC 2004, Cox 2004, DCMS 2004, 2005, 2005a, 2006, 2006a, House of Commons 2004, House of Lords 2005) to consider the terms of the BBC's new Charter. The Government has published the terms of a proposed new BBC "constitution", a new Charter and Agreement (see http://www.bbccharterreview.org.uk/publications/cr_pubs/pub_draftrc_revisedjuly06.html on 27.8.2006) but though these include a new body, the BBC Trust, to replace the present BBC Board of Governors they do not include significant changes in BBC accountability. The conservatism of the Government's proposals reflects the genuine difficulties in devising durable forms of public sector accountability and the dominant conceptual framing of broadcasting citizenship in the UK.

* Professor of Media Studies, The Open University, UK.

\begin{tabular}{l|l|l|l|l|l|} 
Civitas & Porto Alegre & v. 7 & n. 2 & jul.-dez. 2007 & p. 81-107 \\
\hline
\end{tabular}


The discussion below draws on Warnock's (1974) notion of two part accountability (provision of information and ability to exercise sanctions) and on both Hirschman's (1970) and Thompson's (2003) triadic distinctions (respectively between exit, voice and loyalty and hierarchical, market and network forms of governance). I ask how the accountability requirements of giving and holding to account exercised in the contexts defined by Hirschman and Thompson and focus on the role of trust (drawing on O’Neill's 2002 “A question of trust"). In contrast to the "strong” framing of the normative conception of the consumer (see Peacock 1986 and also Potter 1988 and Sargant 1992 and 1993) as an active user who can hold institutions to account in a well functioning market the citizen in broadcasting is constructed (following Marshall 1981) merely as the object of the distribution of welfare rather than as an active agent able to hold providers to account.

\section{BBC Charter review}

The forthcoming expiry of the BBC's Royal Charter in late 2006 has provoked an intense and wide ranging debate about UK broadcasting policy and the role, funding and constitution of the BBC. This debate has taken place in a context where, for the past two and a half decades, institutional co-ordination and governance through markets has greatly increased (liberalisation and privatisation) and hierarchical "command and control" governance has correspondingly diminished and in which much attention has been given to the accountability (substantial number) of public sector institutions which remain subject to hierarchical governance and organisation.

$\mathrm{BBC}$ accountability of the BBC figured prominently among the issues arising from the Department for Culture, Media and Sport's (DCMS) public consultation, ${ }^{1}$ Jonathan Zeff, Head of Broadcasting Policy at DCMS stated:

The governance and regulation of the BBC was obviously one of the key areas of concern..... there was a strong emphasis on the importance of the BBC's in-

1 See several relevant documents including an analysis of consultation responses at http://www.bbccharterreview.org.uk/publications/cr_pubs/pub_gp_summaryresponses.html on 12.4.2006. 
dependence, and there was also clear evidence of a general desire for greater accountability to viewers and listeners, for ensuring that the interests of licencefee payers are properly represented, and for greater transparency in the way that the BBC operates. ${ }^{2}$

Ubiqus, the company undertaking the consultation, summarised respondents' concerns and stated:

"The majority of respondents answering this question [ie about governance RC] wanted the Governors to be more directly accountable to and representative of the general public. This was the key recommendation from the public" (Ubiqus 2004: 33). ${ }^{3}$

Such testimony to dissatisfaction reflects both a general issue in broadcasting policy and regulation in democratic and pluralist societies and the complexity, and sometimes obscurity, of established arrangements for holding the BBC to account in which three institutions play a major role that is Government, Ofcom and the BBC's own Governors.

The Government controls the BBC's public funding by setting the level, and duration, of the licence fee settlement. It determines the BBC's remit by defining the terms under which the $\mathrm{BBC}$ operates, that is the Royal Charter and Agreement between the BBC and the Government (DNH 1996 and see also http://www.bbc.co.uk/info/policies/charter/ on 19.6.2006). It appoints the BBC's Governors and the Ministry responsible for the BBC, the DCMS, has power of approval over new BBC services. In contrast to the important role played by Government in setting the terms on which the BBC operates, Parliament has few powers and responsibilities.

The BBC is also subject to Ofcom, the UK's statutory regulator for electronic media and communications, in respect of so called Tier 1 (harm and offence. fairness and privacy) and Tier 2 matters (notably programme production quotas) and (via provisions in the BBC's Agreement with the Secretary of State) is also bound to adhere to the standards in Ofcom's

2 At The Future of the BBC: Westminster Media Forum Consultation Seminar on the Green Paper. June 2005.

3 It may be unwise to rely on the views expressed on BBC governance and accountability in the consultation. Analysis of responses by Ubiqus (2004: 29) found not only that the question about governance and accountability "was unanswered by the majority of respondents" but that "In the main, responses demonstrated an overwhelming lack of knowledge". 
Broadcasting Code (at http://www.ofcom.org.uk/tv/ifi/codes/bcode/ on 21.6.2006). Ofcom has power to issue directions to, and impose a fine of up to $£ 250,000$ on, the BBC but has fewer powers over the BBC than it has over other broadcasters. ${ }^{4}$

The third element in BBC accountability is the BBC's Board of Governors. The Governors are the $\mathrm{BBC}$ for legal purposes and are thus responsible for all aspects of $\mathrm{BBC}$ activity. Among the chief deficiencies perceived under these arrangements are the Governors' dual roles of governance and regulation (can complainants, whether about accuracy or fair trading or other matters, be assured of fair treatment when the adjudicating body is the governing body?).

\section{Proposals for change}

The Government proposes to change established arrangements by replacing the Governors by a BBC Trust and a separately constituted BBC Executive. The Trust will regulate accuracy and impartiality of programme content, define the scope of the BBC's activities (in service licences, purpose remits and through its power to authorise new services), hold the Executive to account and appoint the Chair of the Executive Board (see DCMS 2006). The Trust will be charged with improving the transparency of the BBC and with a duty to consult licence fee payers. However, viewers' and listeners' powers to hold the BBC to account, either directly or indirectly through their representatives in Parliament will not change.

The Government's proposed changes do not seem commensurate with either the public's wish for the BBC's Governors to be "more directly accountable to and representative of the general public" (Ubiqus 2004: 33) or the dissatisfaction expressed by many of the large number of enquiries which considered the future of the BBC in the course of Charter review. At the time of writing, the Trust remains to be constituted and it's therefore not yet clear how

4 The BBC is also subject to Ofcom (which is the lead competition regulator for the communications sector) in respect of the Competition Act 1998 and Enterprise Act 2002 but the BBC's public service and public sector status mean that some provisions of the Competition Act 1998 and Enterprise Act 2002 are of uncertain application (see Cave, Collins and Crowther 2004). 
it will discharge its responsibilities but what seems to be envisaged is a combination of regular public consultation and straightforward hierarchical, top down, oversight of management by the Trust. The Government's power to define the BBC' mandate, appoint its Governors and set the level and term of the licence fee and Ofcom's powers to issue directions and to fine the BBC will remain unchanged. Like the Board of Governors which preceded it, the Trust will discharge both regulatory and governance responsibilities. But the Trust will be different from the Governors in that it will be more clearly separated from management, more clearly in command and will have explicit duties to consult licence fee payers. Moreover, the Trust will enjoy more clearly defined and more significant authority than did the Governors through its powers to attach conditions to service licences, deny approval to new services, appoint the Chair of the BBC Executive and, as the Government has stated, have the final word (DCMS 2006: 51).

\section{Hierarchy or Market? Accountability through voice and exit}

The substantial continuities between the old and proposed new governance and regulatory regime reflect general problems in making public sector institutions effectively accountable to those whom they serve as well as issues specific to the BBC. Among the general problems are, as is well known, the inapplicability of price based purchaser/provider relationships, the remoteness of large scale institutions from users, the imperfect effectiveness of accountability through Parliament or other elected bodies. Moreover, there are further problems which arise from both the lack of direct contact between provider and user intrinsic to broadcasting and the need to safeguard the BBC's journalistic and editorial independence. The latter consideration militates against control by Parliamentary and/or by any new elected, broadcasting specific, body which might be subject to capture by an unrepresentative group or interest.

What's meant by the terms "accountability", "hierarchical governance" and "market governance”? Mary Warnock ${ }^{5}$ argued that accountability consists in two elements - an entitlement to knowledge and a power to impose sanctions. She stated:

5 Warnock is a member of the House of Lords, a philosopher of established reputation and served as a Member of the Independent Broadcasting Authority. 
A is accountable to B where B has entrusted to A some duty (especially in regard to the spending of money) and where, if A fails to fulfil this duty, B has some sanction which he may use against A. This is one necessary part of it. But it follows that $\mathrm{B}$ has a right to be exactly informed of what $\mathrm{A}$ has done towards fulfilling his duty (Warnock 1974: 2).

Warnock's model could be restated as a duty to give an account (provide information) and be held to account (be subject to sanction). Under the tutelage of the proposed BBC Trust, licence fee payers should be better informed, the $\mathrm{BBC}$ will be required to give a fuller account of itself to the public, but licence fee payers' ability to exercise sanctions, to hold the BBC to account, will change little. One element of Warnock's definition may be better satisfied, ie provision of information, but powers of sanction will remain with the Government, Ofcom and the Trust (the successor to the Governors) rather than with the licence fee payer.

As to the terms hierarchy and markets, governance, or control, of institutions may be exercised through a variety of different forms of coordination notably hierarchies (command and control), markets or networks (Thompson 2003) or a combination thereof. Accountability under hierarchical governance is generally upward whereas accountability in market governance is usually downward. Under network governance, accountability is customarily exercised through collaborative relationships and practices characterised by trust between the parties - one might call this horizontal accountability.

It is a truism to observe that one of the "grand narratives" of UK public sector governance over the last quarter of a century has been a re-balancing towards market and away from hierarchical governance (see, for example, Moran 2003). This has been manifested both through a re-engineering of the internal relationships of public sector bodies to embody the precepts of "new public management” (NPM) on private sector lines (Osborne and Gaebler 1992) as well as through liberalisation and privatisation which reshaped public bodies' outward facing relationships. The growing salience of market, rather than hierarchical, governance in the media and communications sector has been shaped both by technological change and by government policy. Government policy has shifted from inhibiting entry, by licencing of firms, to general authorisation and promotion of entry: in both broadcasting and 
telecommunications monopoly (or duopoly) has given way to competition between hundreds of firms.

This is not to state that markets have completely displaced hierarchy, but rather that, the straightforward command and control systems of hierarchical governance which obtained 50 years ago for broadcasting, post and telecommunications, (that is all UK media and communications except the print sector), have given way to a complex intersection of different governance systems with market (and network) governance assuming a much greater role than before. In domains where, traditionally, hierarchical governance prevailed there has been a pronounced shift towards market governance and in some sectors, notably the Internet, a shift towards network governance and co-regulation. ${ }^{6}$ UK broadcasting including the BBC has come increasingly to be measured against a market template.

\section{Market governance}

In broadcasting, the most powerful and influential case for adoption of market governance and accountability in the UK was made by the Peacock Committee in 1986. Peacock (1986) recommended increasing contestability in broadcasting markets and downward accountability to viewers and listeners. Peacock's argument rested on two propositions, first that viewers and listeners are well able to identify their own needs and interests and thus should be sovereign and, second that, once created, well functioning broadcasting markets would enable viewers and listeners effectively to hold broadcasters to account through the price system which would express the intensities of their preferences. ${ }^{7}$

But, although governance of media and communications over the last 25 years increasingly has been undertaken through markets (with accountability

6 Co-regulation is also growing in broadcasting, for example Ofcom has "outsourced" regulation of television advertising to the private sector self-regulatory body the Broadcast Committee of Advertising Practice (BCAP).

7 The Peacock Committee's argument looked forward to the advent of subscription television but radio posed different problems. The Committee proposed that radio should be financed by a licence fee for car radios (and advertising). However the licence fee method would scarcely advance consumer sovereignty and accountability. 
to users expressed through prices), market governance has notable deficiencies. Each of the two principal means of market funding of broadcasting, advertising and subscription, deny users the ability to express effectively their preferences through prices. Advertising financed programmes and services tend to respond to the interests of the advertisers and to engender clustering of programmes and services in a middle range (the "Hotelling" effect) rather than matching offer and demand effectively (see, inter alia, Peacock 1986, Collins, Garnham and Locksley 1988). Subscription finance, though in theory well fitted to empowering users, tends to bundle services meaning that consumers have to purchase unwanted products and services if they are to secure those they do want and they also have to defray the transaction costs intrinsic to subscription finance. Further, both advertising and subscription funded services tend to super-serve the relatively wealthy and under-serve the relatively poor. Moreover, broadcasting markets may be distorted by dominant firms exercising market power in any or all areas of a complex supply chain (including content, encryption, electronic programme guides, subscription management, platform control) to chill and/or foreclose entry to broadcasting markets to the detriment of consumers (see, inter alia, Cox 2004: 50-53).

These deficiencies in market governance of broadcasting have justified the continued public service and public sector presence in UK broadcasting but latterly the issues of proportionality (the appropriate size of the public element in broadcasting) and accountability have increasingly figured in UK broadcasting policy debates.

\section{Exit, voice and loyalty}

In 1970 Albert Hirschman published his "Exit, Voice and Loyalty" (Hirschman 1970) in which he identifies three ways in which stakeholders can hold institutions to account - through exercise of what he called "exit", "voice" and "loyalty". Different governance systems provide different means for stakeholders to signal their preferences by exiting from the relationship (eg by ceasing to buy products and services), making their voice heard (eg by voting) or by demonstrating their loyalty (doing nothing in circumstances where the alternatives of exit and/or voice are available). 
If "loyalty" is regarded as a null option (if one is loyal then one does not exercise voice or exit) "exit" is principally an option to be exercised through market systems of accountability and "voice" is principally an option to be exercised through hierarchical systems of accountability. Or put more pithily, exit is exercised through price and voice through politics. Applying Hirschman's model to broadcasting shows that there are significant inadequacies in the prevailing accountability mechanisms of both market and hierarchical systems. In market systems, whether advertising or subscription funded, viewers and listeners are unable effectively exercise the sanction of voice (though they may write, 'phone in or formally complain) but they do have exit sanction powers. In advertising funded systems their exit reduces revenue from advertisers. In subscription funded systems exit has direct and adverse financial consequences for broadcasters.

For the BBC, hierarchically organised and funded, viewers and listeners have few opportunities to either exercise voice or exit. ${ }^{8}$ They are unable to represent their preferences to the $\mathrm{BBC}$, ie exercise voice, because the BBC lacks the institutional forms of either joint stock companies (shareholders' meetings, election of directors, reporting requirements defined by stock exchanges and financial regulators) or democratic politics (notably the election of representatives) through which "voice" can be expressed. And nor are viewers, licence fee payers, ${ }^{9}$ able to lawfully exit from their relationship with the BBC (other than by abstaining from all television consumption).

In Hirschman's terms, the public is unable effectively to hold the BBC to account because it is unable to exercise either voice or exit. Public disenfranchisement appears increasingly anomalous as devices such as computers and mobile 'phones and the Internet enable users to more effectively control consumption and as voice (and often exit) accountability

8 True, viewers and listeners may cease to consume BBC programmes but this has no obvious financial impact on the BBC (BBC funding has risen over the last decade although its share of television, but not radio, consumption has fallen). However, it seems likely that there is a "tipping point" at which compulsory licence fee funding would cease to have legitimacy because too few watched or listened to BBC services. That point has yet to be reached.

The licence fee is a charge only on television viewers - currently there is no radio licence in the UK. The licence fee is formally classified as a tax by the Office of National Statistics (ONS 2006). 
is augmented in other public sector institutions. Loyalty, rather than being chosen, is made compulsory. 


\section{The BBC, trust and horizontal accountability}

The BBC enjoys a very special status as a publicly owned body which is weakly subject to external hierarchical governance and upward accountability and is not subject to market governance and downward responsibility to users. The self-regulatory and self-authorising status of the BBC has rested on public trust in the BBC rather than on the ability of the public to hold the $\mathrm{BBC}$ to account through exercise of either exit or voice. How widely is the $\mathrm{BBC}$ trusted and how well founded is that trust?

O'Neill (2002) has persuasively argued that trust based systems of governance have formidable advantages and that when trust is present formal accountability is not required. She also, cleverly, shows that formal systems of accountability are in the end based on trust because, in the end, all accountability chains have to end somewhere and there be anchored in a final trusted authority. Though the BBC remains among the best trusted of UK organisations it has neither been immune from the pervasive mistrust and suspicion which O'Neill has argued "have spread across all areas of life" (O’Neill 2002: 8) nor has it been innocent of actions which have been corrosive of trust.

Mori research (Mori 2003: 12) found that television was second only to the army among trusted institutions in the UK (and radio followed fourth after the police). Although neither the radio nor the television about which Mori asked respondents maps perfectly onto the BBC it seems highly unlikely that were the BBC (with c 38\% of television consumption and c53\% of radio consumption) to be widely mistrusted Mori would not have found such high levels of general trust in broadcasting. YouGov found, ${ }^{10}$ in a poll conducted in January 2005, that the BBC is "still the most trusted for news" (though Sky News is more trusted than the BBC's News 24). Abundant testimony to the high levels of public trust in the BBC was also evident at the time of the Gilligan affair and the subsequent Hutton enquiry when public sentiment inclined towards the BBC rather than the Government.

10 YouGov press release at http://www.yougov.com/archives/pdf/OMI050101003_2.pdf on 27.2.2006. See also (BBC 2004a: 45). 
Nonetheless, Lord Hutton's probe (Hutton 2004) into the "Gilligan affair" revealed how some aspects of the BBC's journalistic and editorial procedures had fallen short of the high standards on which public trust has been based. ${ }^{11}$ Others have observed that in some respects the BBC's procedures fall short of those adopted by other highly reputed news organisations - see, for example, BBC 2006). Further, O’Neill (2004a) has observed that:

Reuters' journalists.... face disciplines that those who work for the BBC.... do not face. Journalists and editors working for ..... the BBC do not routinely have to declare their interests, or their conflicts of interest to their managers (let alone their audiences) or to withdraw from broadcasting on topics in which they have a financial interest.

Different aspects of BBC conduct, such as those revealed in the PKF report on BBC funding (DCMS 2006b) and some of the National Audit Office's (NAO) reports on value for money (see http://www.bbcgovernors. co.uk/docs/rev_valueformoney.html on 20.6.2006) achieved by the BBC, have also qualified public trust in the BBC. Further pillars of the BBC's raison d'etre, such as the public service quality and character of its programmes have also come under criticism, for example the Green Paper stated that BBC programmes are "too dull, or too copy-cat of formats working perfectly adequately” (DCMS 2005a: 2). ${ }^{12}$ Moreover, recent enquiries into specific aspects of BBC journalism (such as BBC reporting of the European Union and the Israel/Palestine conflict - see BBC 2005b and 2006) ${ }^{13}$ also found grounds for criticism and the sheer volume of recent studies and enquiries into the BBC suggest some generalised disquiet about aspects of its performance and grounds. The BBC and its proponents, on

11 The BBC's own reflections on its journalistic and editorial practices, the Neil Report, (BBC 2004b) constructively acknowledged that the BBC had a case to answer and that its procedures and training should be improved (the BBC has adopted the Neil Report and begun to implement its recommendations).

12 See also inter alia BBC 2005, 2006, DFID 2002, Cox 2004: 64.

13 To invoke the findings of National Audit Office studies of the BBC's operational performance and the findings of enquiries into the quality and character of BBC journalism may suggest that the BBC is damned if it does and damned if it doesn't. There can be no doubt that the commissioning, formally by the Governors, and publication of such studies betokens a laudable transparency in BBC governance and perhaps a healthy institutional culture of self-criticism. 
the other hand, have often argued that the BBC's editorial independence (the desirability of which is very seldom challenged) depends on its selfauthorising "independent" status. But, as the House of Commons Select Committee observed, there is no necessary incompatibility between independence and accountability. The Committee claimed that "independence does not by any means absolve the BBC from ex post accountability for its performance and its use of a substantial amount of the public's money” (House of Commons 2004: 64).

Although neither well founded trust in the BBC nor a well functioning system of formal accountability to viewers and listeners can be taken for granted, the process of Charter review 2004-6 itself has meant that the BBC has been subject to a much higher degree of external scrutiny than is usually the case. This in itself is a form of holding to account, and one which has elicited much information and thus made significant steps towards satisfying one of Warnock's two components of accountability provision of information. Although Charter review takes place infrequently (the current Charter dates from 1996 and expires in 2006), the BBC is also subject to what might be called a perpetual plebiscite on the part of viewers and listeners (as it competes for their attention against alternative viewing and listening opportunities) though an adverse verdict in such a plebiscite has not, yet, been attended by the exercise of sanctions. However, in spite of the force of such informal systems of accountability the BBC remains strikingly insulated from direct accountability to its users.

\section{Club governance and (in)competent viewers and listeners}

The complex articulation of different systems of holding the BBC to account exist in a context of accumulating evidence that high levels of public trust in the BBC are not grounded in consistently high levels of BBC performance. O'Neill's proposition "Traditional approaches to compliance relied heavily on cultures of trust” (O'Neill 2005: 1) does much to explain both why formal systems of holding the BBC to account have been patchy and underdeveloped and why there are now unprecedented levels of demand for greater formality and effectiveness in BBC accountability mechanisms. 
The BBC's governance arrangements reflect the survival of "club governance" (Marquand 1988, Moran 2003) that is governance based on shared understandings, assumptions and trust between parties which Marquand described as:

The atmosphere of British government was that of a club, whose members trusted each other to observe the spirit of the club rules; the notion that the principles underlying the rules should be clearly defined and publicly proclaimed was profoundly alien (Marquand: 1988: 178).

Club governance, epitomised by UK broadcasting Moran (2003), exemplifies the demerits of trust based systems. But, as O'Neill and Power (1997) have pointed out alternatives to trust based accountability have notable demerits - see their persuasive critiques of target setting, quantification and the intrusive apparatus and perverse outcomes of the "audit society". These demerits may go far to explain the longevity of established, albeit creaky and complex, arrangements in respect of the BBC.

\section{Transparency and consultation}

The $\mathrm{BBC}$ has acknowledged that it has "historically been rather closed as an institution" (BBC 2004: 19) and that reform should "make the BBC more responsive and accountable to the British public" (BBC 2004: 23). Both the BBC, in "Building Public Value" and the Government, in the Green Paper, have proposed to improve BBC accountability to its viewers and listeners by providing more information, that is better giving an account - one dimension of Warnock's stipulation. The BBC has proposed (BBC 2004: around 131) to strengthen its established advisory councils, institute a tri-annual public value survey by polling a large representative sample of the UK population and to improve complaints handling. The Government, in the Green Paper (DCMS 2005a: around 12), proposed that deliberative research should inform the BBC's governing body's major decisions, that meetings of the Trust should take place in public and/or be webcast and more speculatively canvassed the possibility of electing members of the BBC's advisory councils and of publishing the voting records of Trust members. The Government also 
advocated improved complaints handling by the BBC. ${ }^{14}$ Rather than endowing viewers and listeners with the power to hold the BBC to account, the Government proposes to keep this power with the Trust, the successor to the BBC Governors and the body which, formally and legally is the BBC, and charge the Trust with to give a better account of the BBC to viewers and listeners than did the Governors.

Proposed changes to the BBC's governance seldom include strengthening, whether through voice or exit, the power of viewers and listeners to hold the BBC to account. Rather, in varying degrees, they advocate revisions to the established system of upward, hierarchical, accountability rather than strengthening downward accountability to viewers and listeners, whether through market, exit, or hierarchy, voice. This stance towards the BBC contrasts with a general social trend (see Blaug, Horner and Lekhi 2006) towards greater user and citizen participation in the determination of policy and practice of public sector institutions.

Why should the BBC be an exception to this trend? Essentially because viewers and listeners are not though to be competent judges of their own needs and interests. In part this reflects a general relationship between professional experts and non-experts - it's appropriate and customary for non-experts to defer to experts - in education, medicine, law and other domains. In part it reflects the BBC's sedulous guardianship of its independence, recently exemplified in its rejection (on the grounds that the electoral process might be subject to capture) of election of members of its advisory committees. ${ }^{15}$ In part it's a legacy of Reith's notion of users of BBC services as incompetent to judge their own needs. ${ }^{16}$ And in part an aspect of

14 Complaints handling by public bodies was the subject of a study by the National Audit Office (NAO) but the BBC was not among the 277 public bodies surveyed by the NAO in its study "Citizen Redress" (NAO 2005). Nonetheless, the BBC has implemented important improvements in its complaints handling.

All the BBC's (and BBC appointed) advisory bodies have refused to brook election of their members (BBC 2005a: 94, 97, 100, 103). And the BBC, perhaps rather ventriloquistically, supported them (BBC 2005a: 59).

16

Reith's comment provides a representative flavour of this sentiment: "In earliest years accused of setting out to give the public not what it wanted but what the BBC thought it should have, the answer was that few knew what they wanted, fewer what they needed" (Reith 1949: 101). 
the BBC's role as provider of "merit goods" ${ }^{17}$ individuals are likely to "under demand" merit goods, goods and services beneficial to society as a whole, when greater benefits accrue to society than accrue to the individuals making the demand decisions.

Viewing users of broadcasting services as incompetent to decide leads necessarily to a rejection of viewer and listener sovereignty over the BBC. But such a conception of the viewer and listener risks leaving the BBC marooned as an isolated relic of "club governance" and under-developed downward accountability at a time when other public sector bodies (see, inter alia the Public and Patient Involvement forums established by all NHS Trusts and the Home Office's requirement that the police engage and involve communities in crime reduction and priority setting. [See Department of Health 2003 and Home Office 2004]) are strengthening their accountability to users and when consumer sovereignty is more and more salient an objective in market governance.

\section{The consumer and the citizen in broadcasting}

The growth of the market sector in communications (and the impact of New Public Management and privatisation on the public sector) has led some to defend the BBC as a public sector bastion distinguished by its "citizenship" orientation and values as opposed to the "consumer" values and orientation of the market sector. ${ }^{18}$ In consequence the user of broadcasting services has come to be conceived dualistically as both a citizen and as a

17 "Merit goods", in the language of neo-classical economics, are goods which confer long term benefits but which no individual thinks worth paying for. Examples include high culture, scientific research, education etc. Because free markets tend to undersupply merit goods it's generally accepted that there is a legitimate role for the state in providing them - hence public funding for education, the arts, research and public service broadcasting. Without the justification afforded by its provision of merit goods the legitimacy of both public funding and a system of governance offering those who pay few opportunities either to "exit" or exercise their "voice" (see Hirschman 1970).

18

Pattie, Seyd and Whitely (2004: 77) sensibly acknowledge the porous boundaries between the notions of consumer and citizen when observing that "in their day to day consumption behaviour they [ie people in the UK RC] are acting politically" and argue that the nature of political participation in the UK "makes it meaningful to talk about 'consumer citizenship"” (Pattie, Seyd and Whitely 2004: 267). 
consumer (or as a hybrid citizen/consumer) with different accountability relationships attaching to each identity. 
Accountability to consumers, normatively, is to be realised by enabling consumers to make (or not make) purchases from one or more of a number of competing providers. Within this sort of normative schema public service broadcasting, and the BBC in particular, looks at best somewhat odd and at worst appears as a major obstacle standing in the way of a well functioning market through which consumers are able to hold producers and providers accountable through the price system. Accountability to citizens, on the other hand, is more difficult to define (but see Calabrese and Burgelman 2003, Hartley 1999, Murdock 1999, 1999a, 2004, Stevenson 2003) and to realise. The term "citizen" has been given a particular inflection in discussions of UK broadcasting policy and this inflection has marginalised accountability questions. The notion of citizenship as a power to share in decision making (see inter alia Brinckmann 1930) or, in Hirschman's terms to exercise voice, has scarcely been considered, still less implemented. Perhaps the fear of what Heller (1978: 2) wittily identified as the unwelcome possibility of a "Hobbesian state of anarchy and disruption" which might attend the exercise of a "public right to intervene in the management of services" is the reason for this absence. Fear of Hobbesian horror, rather than fear of "public service bureaucracies that are insulated from public or parliamentary scrutiny and effectively independent in their pursuit of organisational objectives and growth" (Heller 1978: 2) has been stronger in informing public policy and practice.

\section{Consumer and citizen}

The shift towards market, and away from hierarchical, governance in broadcasting has led to what Murdock called "the figure of the consumer and the ideology of consumerism” (Murdock 1999:10) rising in salience. Consumerism, Murdock proposes, is hostile to citizenship and the values implied in the category "citizen": consumerism "privileges personal spending over social and political participation, and addresses viewers as shoppers rather than as members of intersecting moral communities" and "by equating social differences with variations in choice and style it negates any attempt to arrive at a conception of the 'common good' based on the negotiation of differences in their full complexity” (Murdock 1999: 10). This view, though representative, acknowledges insufficiently the concern for liberty rather than self-interested consumption, which has informed the major UK arguments for consumer 
sovereignty in broadcasting and notably the report of the Peacock Committee in 1986. Further, it masks the complementarities between "citizenship" and "consumer" values in the arguments advanced by proponents of the consumer interest (see, for example, NCC 1993, Potter 1988, and Sargant 1992, 1993). Moreover the version of citizenship characteristically mobilised in the UK broadcasting discourse puts forward an amputated notion of citizenship because insufficiently acknowledging a normative capacity to share decisions a notion strongly indebted to the work of T H Marshall.

\section{Citizenship}

Marshall is the most cited author ${ }^{19}$ in the index to Calabrese and Burgelman's collection of essays on citizenship and communications and Marshall's thought is the source of the "welfarist" move characteristically evident in contemporary scholarly discussion of broadcasting and citizenship. The welfarist move, I argue, constitutes broadcasting as one of a bundle of welfare rights and thereby extends Marshall's triad of rights (civic, political and social) to encompass additional putative broadcasting related rights.

Calabrese usefully summarises Marshall (Calabrese and Burgelman 1999: 261) as having defined citizenship as consisting in three elements, each realised at a distinct historical moment: first, civic rights (secured in Western Europe in the C18th); second, political rights (secured in Western Europe at the end of the C19th) and, third, welfare rights (secured in Western Europe in the C20th ${ }^{20}$ ).

Marshall's triadic bundle of rights (civil, political and social) provides a template for a number of influential accounts of citizenship and the media. Murdock (1999a: 29-30), for example, extends Marshall's bundle to include a further putative type of right - information and cultural rights and has argued that "the core rationale for public service broadcasting lies in its commitment to providing the cultural resources required for full citizenship” (Murdock 2004: 2). Hartley (1999: 179) further extends the definition of citizenship to include

19 Castells and Habermas score the same number of citations in the index.

20 We may pass over this occidental perspective as not unreasonable when addressing so western a phenomenon - the notable oriental instances of Indian, Japanese and Taiwanese public service broadcasting notwithstanding. 
not only this fourth form of citizenship, cultural citizenship, but a fifth: DIY Do it Yourself - citizenship.

Marshall and his successors thus offer a notion of citizenship as onion: each bundle of citizenship entitlements/attributes surrounds the others concentrically and in complementary and non-rival fashion. But all layers of the onion must putatively be present if the entitlements of citizenship are to be fully realised - Marshall added a third layer - social rights - to a preexisting two layer onion - civic and political rights - and Murdock, Hartley and others have added further layers (notably the cultural and/or informational and the DIY layers). However, these definitions do not include either of the two attributes of citizenship identified by Brinkmann in his classic commentary in the Encyclopaedia of the Social Sciences, notably: "the notion of liberty... and membership of a political unit involving co-operation in public decisions as a right and sharing of public burdens... as a duty” (Brinkmann 1930: 471).

Marshall's, and post-Marshallian's, conceptions of citizenship construct citizenship passively, as a series of entitlements - or as Marshall puts it "rights and legitimate expectations", rather than as an active, participatory and creative practice. ${ }^{21}$ Citizenship is thus a condition of competence legitimately to make claims on others within a polity. It does not include the power to hold authority to account or to participate in making decisions.

In contrast, consumer centred notions of broadcasting accountability have foregrounded users ability to exercise control and deploy effective sanctions. The Peacock Committee in 1986, in a report which remains the most articulate and well reasoned statement of consumer based accountability in broadcasting, advocated a "sophisticated market system based on consumer sovereignty" (Peacock 1986: para 592). Such a system would, the Committee argued, enlarge "the freedom of choice of the consumer" (Peacock 1986: para 547). The Peacock Committee sought a well functioning market based broadcasting system because such a market was conducive to liberty,

21 Pattie, Seyd and Whitely (2004: 10) observe that "Marshall's 'linear, cumulative model' of the development of citizenship is problematic, but is nevertheless a starting point for debates about contemporary citizenship in Britain”. 
competition and markets were embraced only secondarily for their putative economic efficiency. 


\section{Consumer and citizen: concepts in action}

The terms, consumer and citizen, was embedded in UK broadcasting law for the first time in the Communications Act 2003 (CA 2003) which requires Ofcom $^{22}$ to further the interests of citizens and consumers. The CA 2003 defines "citizen" as "all members of the public in the United Kingdom" (1.3.14) but does not define "consumer" (though the Act attributes particular importance to consumers' interests, notably "in respect of choice, price, quality of service and value for money” (1.3.5)). The Act requires Ofcom:

(a) to further the interests of citizens in relation to communications matters; and

(b) to further the interests of consumers in relevant markets, where appropriate by promoting competition. (CA 2003 3.1).

Since the CA 2003 came into effect the BBC (2004a), the Government (DCMS 2006) and Ofcom (2004c) have all put forward accounts of broadcasting and citizenship. The Government's White Paper on the future of the BBC "A public service for all: the BBC in the digital age" (DCMS 2006) is representative and fills out notion of citizenship first put forward in the CA 2003. It identifies "sustaining citizenship and civil society" as the first of the six public purposes with which the BBC is charged.

The remaining five purposes are:

- Promoting education and learning;

- Stimulating creativity and cultural excellence by using the licence fee as venture capital for creativity;

- Representing the UK, its nations and regions;

- Bringing the UK to the world and the world to the UK;

- Building digital Britain.

The White Paper further elaborates the BBC's citizenship mandate (DCMS 2006: 13) as a duty to:

- Inform the public and increase understanding of the world through news, information and analysis of current events and ideas;

22 Ofcom, the Office of Communications, is the integrated regulator of electronic communications which replaced five former agencies and which was created under the 2003 Communications Act. 
- $\quad$ Set standards of quality in news and current affairs;

- $\quad$ Engage the widest possible cross-section of the UK population with differently-targeted services, including BBC Online;

- Continued commitment to local and regional news;

- Stimulate engagement with social and political issues through programming outside news and current affairs - e.g. through themed seasons or campaigns;

- Help people understand Parliament and the UK political system including the devolved administrations; BBC Parliament should continue to carry dedicated coverage of Parliamentary matters, and there should be regular coverage of Parliament in both news and other programming on mainstream channels;

- Contribute to democratic debate in forms other than broadcast content - for example by organising seminars and e-discussion forums, distributing information and working on campaigns with partners in the public and voluntary sector - within clear boundaries;

- Implement the core recommendations of the Neil report. ${ }^{23}$

Broadcasting's citizenship vocation is thus designated as a provision of information to viewers and listeners - it fits neatly the welfarist thrust of Marshall's notion of modern citizenship. In contrast, when broadcasting's relationship to viewers and listeners as consumers is under discussion, the idea of sovereignty, mobilized by the Peacock Report, is of considerable importance. For example, Ed Richards, Ofcom's Chief operating Officer (and formerly Senior Policy Advisor to the Prime Minister for Media and earlier Controller of Corporate Strategy at the BBC), stated (all citations from Ofcom 2004c):

As consumers, our concern is that we are supplied with what we as individuals, or perhaps on behalf of our families, want to watch or what we want to have an option to watch.

And he further proposed, (as the Peacock Committee in 1986 had envisaged), that:

23 The Neil report (BBC 2004b) responded to Lord Hutton's criticisms of BBC journalism and proposed measures to improve it. 
post analogue switch off we will see the evolution of something approaching a reasonably well functioning market in broadcasting....... consumers, through their own choices will be able to express their preferences - through what they choose to watch, what they choose to subscribe to or what they choose to buy on a per view basis.

In these representative statements by the principal policy actors broadcasting's role in respect of the citizen is defined (whether broadly or narrowly) as the provision of socially desirable content by broadcasters. Whereas the relationship between broadcasting and the consumer is conceived normatively as one in which consumers are able to express and realise their preferences. The rhetorical construction of the broadcasting citizen and the broadcasting consumer is that being a citizen is to have provided by an authority: control resides outside the citizen. Whereas, being a broadcasting consumer is to be in control of what one watches (or listens to): control resides with the consumer.

\section{Conclusion}

The debate about the future of the BBC which took place in the UK throughout 2004-2006 was remarkable for its range and intensity although finally resulting in something very like the status quo ante for the BBC. The accountability of the BBC, although a matter on which both the public expressed its concern in the Government's consultations and Parliamentary and other enquiries expressed views in the wealth of commentaries and reports which appeared during Charter review, remains much as it was before. True the Trust is charged to give viewers and listeners a better and fuller account of the BBC than was, and did, the Governors. True, the Trust is to be more clearly distinguished from the BBC management than was its predecessor and may therefore be better able to hold the BBC to account. But little changes in the crucial relationship between the user and the broadcaster. Whether as consumer or citizen the viewer and listener disposes of few powers to hold the BBC to account.

This is because, first, the viewer and listener's relationship to the BBC, in respect of formal accountability, is conceptually constructed as a relationship of citizenship (rather than of consumption) and because, second, there is a clear normative rhetoric in both scholarly and policy domains which constructs 
broadcasting citizenship as a derivative of the content which broadcaster(s) provide for viewers and listeners: content the consumption of which, it's assumed, will foster citizenship properties in viewers and listeners. ${ }^{24}$ This then is a passive conception of citizenship. Whereas the consumer of broadcasting is, normatively at least, able to exercise choice $-\mathrm{s} / \mathrm{he}$ is constructed as an active agent. In consequence the viewer and listener is compelled to trust, s/he has neither voice nor exit and thus enjoys no alternative to loyalty. For s/he has, at best, only an account of the BBC given by an unchosen representative, the Trust, rather than the ability to hold to account which, normatively, a nonMarshallian citizen might enjoy.

\section{References}

BBC. Building public value. Renewing the BBC for a digital world. London: BBC, 2004.

BBC. The BBC's contribution to informed citizenship. London, 2004a. At http://www.bbccharterreview.org.uk/pdf_documents/BBC_submission_informed.pdf on 16.2.2006.

BBC. The BBC's Journalism after Hutton. The Report of the Neil Review Team. London: BBC, 2004b. At http://www.bbc.co.uk/info/policies/pdf/neil_report.pdf on 26.2.2006.

BBC. Governors' Genre Review: Current Affairs Television. London: BBC Governance Unit, 2005. At

http://www.bbcgovernors.co.uk/docs/reviews/current_affairs_review.pdf on 25.6.2006.

BBC. Review of the BBC's Royal Charter: $B B C$ response to A strong $B B C$, independent of government. London: BBC, 2005a. At

http://www.bbc.co.uk/thefuture/pdfs/green_paper_response.pdf on 28.12.2005.

BBC. BBC News Coverage of the European Union. Independent Panel Report,2005b. At http://www.bbcgovernors.co.uk/docs/reviews/independentpanelreport.pdf on 11.7.2006.

BBC. Report of the Independent Panel for the BBC Governors on Impartiality of BBC Coverage of the Israeli-Palestinian Conflict, 2006. At http://www.bbcgovernors.co.uk/docs/reviews/panel_report_final.pdf on 25.6.2006.

24 There is, of course, no necessary correspondence between the normative and the empirical. 
BLAUG, R.; HORNER, L.; LEKHI, R. Public Value, Politics and Public Management. A Literature Review. London: The Work Foundation, 2006.

BRINKMANN, C. Citizenship. In: Encyclopaedia of the Social Sciences. New York: Macmillan, (1959 [1930]), 471-474.

CA. Communications Act 2003. Chapter 21. at:

http://www.legislation.hmso.gov.uk/acts/acts2003/20030021.htm on (31.10.2003)

CAlABRESE, A.; BURGElmAN, J. C. (eds.). Communication, Citizenship and Social Policy. Lanham, MA: Rowman and Littlefield, 1999.

CAVE, M.; COLLINS, R.; CROWTHER, P. Regulating the BBC. In: Telecommunications Policy V 28, 2004: 249-272.

COLLINS, R.; GARNHAM, N.; LOCKSLEY, G. The Economics of Television. The UK Case. London: Sage, 1988.

COX, B. Free for All? Public Service Television in the Digital Age. London. Demos, 2004. At http://www.demos.co.uk/media/freeforall_page378.aspx on 29.3.2005

DAVIES, G. The BBC and Public Value. In: HELM, D et al. Can the Market Deliver? Funding Public Service Television in the Digital Age. Eastleigh: John Libey, 2005, p. $129-150$.

DCMS [Department for Culture Media and Sport]. Independent Panel's Report “Emerging Themes” London: DCMS, 2004. At http://www.bbccharterreview.org.uk/pdf_documents/041130_emerging_themes.pdf on 29.3.2005

DCMS [Department for Culture Media and Sport]. Independent Panel's Final Advice to the Secretary of State. London: DCMS, 2005. At

http://www.bbccharterreview.org.uk/pdf_documents/050123a_Governance.pdf on 29.3.2005

DCMS [Department for Culture Media and Sport]. Review of the BBC's Royal Charter: A Strong BBC, Independent of Government. London: DCMS, 2005a. At: http://www.bbccharterreview.org.uk/have_your_say/green_paper/bbc_cr_greenpaper. pdf on 29.3.2005

DCMS. A public service for all: the BBC in the digital age. London: DCMS, 2006. At: http://www.bbccharterreview.org.uk/have_your_say/white_paper/bbc_whitepaper_ma rch06.pdf on 7.4.2006. 
DCMS. Regulatory Impact Assessment: BBC Charter Review. London: DCMS, 2006a. At: http://www.bbccharterreview.org.uk/have_your_say/bbccr_ria_mar06.pdf on 7.4.2006.

DCMS. Review of the BBC Value for Money and Efficiency Programmes. [The PKF Report], 2006b. At

http://www.bbccharterreview.org.uk/pdf_documents/pkfreport_bbcfundin0406.pdf on 21.5.2006.

Department of Health. Briefing Note, 2003. At

http://www.dh.gov.uk/assetRoot/04/07/42/88/04074288.pdf on 14.8.2006.

DFID [Department for International Development]. Viewing the World. A study of British Television Coverage of Developing Countries. London: DFID, 2002. At http://www.dfid.gov.uk/pubs/files/viewworldfull.pdf on 12.1.2005

DNH [Department of National Heritage]. Royal Charter for the continuance of The British Broadcasting Corporation, 1996. At http://www.bbcgovernors.co.uk/about/charter.pdf on 27.1.2006.

GRAHAM, A. Broadcasting Policy in the Multimedia Age. In: GRAHAM, A et al. Public Purposes in Broadcasting. Luton: University of Luton Press, 1999, p 17-46.

GRIPSRUD, J. (ed.). Television and Common Knowledge. London: Routledge, 1999.

HARTLEY, J. Uses of Television. London: Routledge, 1999.

HELLER, C. Broadcasting and Accountability. London: British Film Institute, 1978.

HIRSCHMAN, A. Exit, Voice and Loyalty: Responses to Decline in Firms, Organizations, and States. Cambridge: Harvard University Press, 1970.

Home Office. Building Communities, Beating Crime A better police service for the 21st century. Cm 6360. London: TSO, 2004. at http://police.homeoffice.gov.uk/newsand-publications/publication/police-reform/wp04_complete.pdf?view=Binary on 14.8.2006.

House of Commons Select Committee on Culture Media and Sport. A Public BBC. First Report of Session 2004-05, Vols I and II HC 82-I and HC 82-II. Norwich. TSO, 2004.

House of Commons Committee on Public Accounts. The BBC's White City 2 Development. Twenty-fourth Report of Session 2005-06. HC 652. London: TSO, 2006. 
http://www.publications.parliament.uk/pa/cm200506/cmselect/cmpubacc/652/652.pdf on 14.2.2006.

House of Lords Select Committee on the BBC Charter Review. The Review of the BBC's Royal Charter. First Report of Session 2005-06, Vols I and II. HL 50-I and Hl 50-II. Norwich: TSO, 2005. At

http://www.publications.parliament.uk/pa/ld200506/ldselect/ldbbc/50/50ii.pdf on 21.5.2006.

HUTTON, the Lord. Report of the Inquiry into the Circumstances Surrounding the Death of Dr David Kelly C.M.G. HC 247. London, 2004. At

http://www.the-hutton-inquiry.org.uk/content/report/index.htm on 29.3.2005.

MARQUAND, D. The Unprincipled Society: New Demands and Old Politics. London: Jonathan Cape, 1988.

MARSHALL, T. The Right to Welfare. London: Heinemann Educational, (1981 [1972]).

MARSHALL, T. Welfare in the Context of Social Policy. In: MARSHALL, (1981a [1972]): 67-82.

MORAN, M. The British Regulatory State. High Modernism and Hyper-Innovation. Oxford: OUP, 2003.

MORI. Trust in Public Institutions for the Audit Commission. Undertaken in 2002, 2003:12. At: http://www.mori.com/sri/pdf/final.pdf on 22.5.2006.

MURDOCK, G. Rights and representations: public discourse and cultural citizenship. In: GRIPSRUD, J. (ed.). Television and Common Knowledge. London: Routledge, 1999, p. 7-17.

MURDOCK, G. Corporate Dynamics and Broadcasting Futures. In: MACKAY and O’SULLIVAN (eds.), 1999a, p. 28-42.

MURDOCK, G. Building the Digital Commons: Public Broadcasting in the Age of the Internet. The 2004 Graham Spry Memorial Lecture, 2004. At http://www.com.umontreal.ca/spry/spry-gm-lec.htm on 12.1.2005.

NAO [National Audit Office]. Citizen Redress: What citizens can do if things go wrong with public services. Report by the Comptroller and Auditor General. HC 21 Session 2004-2005. London: TSO, 9 March 2005.

NAO [National Audit Office]. Public service broadcasting: the BBC's performance measurement framework. London: NAO, 2005a. At 
http://www.bbcgovernors.co.uk/docs/reviews/VFM_PSB_webversion.pdf on 14.2.2006).

NAO [National Audit Office]. The BBC's White City development: the second phase of the building project. London: NAO, 2005b. At

http://www.bbcgovernors.co.uk/docs/reviews/VFM_White_City_webversion.pdf on 25.6.2006.

NCC [National Consumer Council]. A Broadcasting Consumers' Council. Response to the Consultation Document The Future of the BBC. London: NCC, 1993.

Ofcom. Ofcom review of public service television broadcasting. Phase 1 - Is television special? London: Ofcom, 2004. At:

http://www.ofcom.org.uk/consult/condocs/psb/psb/psb.pdf on 23.2.2006

Ofcom. Ofcom review of public service television broadcasting. Phase 2 - Meeting the digital challenge. London: Ofcom, 2004a. At:

http://www.ofcom.org.uk/consult/condocs/psb2/ on 23.2.2006.

Ofcom. Assessment of the Market Impact of the BBC's New Digital TV and Radio Services. London: Ofcom, 2004b. At:

http://www.ofcom.org.uk/tv/psb_review/reports/bbcnews.pdf on 23.6.2006.

Ofcom. Speech of 25/5/2004 to the Westminster Media Forum by Ed Richards, Senior Partner, Strategy \& Market Developments, Ofcom on Ofcom's Review of Public Service Television Broadcasting, 2004c.

http://www.ofcom.org.uk/media_office/speeches_presentations/richards_20040525?a $=87101$ on 16.11 .2004

Ofcom. Ofcom review of public service television broadcasting. Phase 3 London: Ofcom, 2005. At http://www.ofcom.org.uk/consult/condocs/psb3/ on 29.3.2005.

O’NEILL, O. A Question of Trust. Cambridge: Cambridge University Press, 2002.

O’NEILL, O. Accuracy, Independence, and Trust in Runciman, W ed "Hutton and Butler. Lifting the Lid on the Workings of Power” Oxford: OUP, 2004.

O’NEILL, O. Rethinking Freedom of the Press. Dublin: Royal Irish Academy, May, 2004a (text provided to the author as personal communication).

O’NEILL, O. Justice, Trust and Accountability. (text provided to the author in English as personal communication. Published in German as "Gerechtigkeit, Vertrauen und Zurechenbarkeit”. In: Gerechtigkeit: Auf der Suche nach einem Gleichgewicht. NEUMAIER, Otto; SEDMAK, Clemens; ZICHY, Michael; VERLAG, Ontos (eds.). Frankfurt, 2005, 33-55. 
ONS [Office of National Statistics]. Classification of Public Sector Television. News Release 20.1.2006. At http://www.statistics.gov.uk/pdfdir/cpst0106.pdf on 17.2.2006.

OSBORNE, D.; GAEBLER, T. Reinventing government: how the entrepreneurial spirit is transforming the public sector. Reading, MA; Wokingham: Addison Wesley, 1992.

PATTIE, C.; SEYD, P.; WHITELEY, P. Citizenship in Britain: Values and Participation. Cambridge: Cambridge University Press, 2004.

PEACOCK, Alan [Chair]. Report of the Committee on Financing the BBC. Cmnd 9824. London: HMSO, 1986.

POTTER, J. Consumerism and the Public Sector: How well does the Coat fit? Public Administration 66, 1988: 149-164.

POWER, M. The audit society: rituals of verification. Oxford: Oxford University Press, 1997.

REITH, J. Into the Wind. London: Hodder and Stoughton, 1949.

SARGANT, N. Broadcasting Policy: Listening to the Consumer. London: Consumers' Association, 1992.

SARGANT, N. Listening to the Consumer. Consumer Policy Review 3.3 159-166. London: Consumers’ Association, 1993.

STEVENSON, N. Cultural Citizenship. Maidenhead. Open University Press, 2003.

THOMPSON, G. Between Hierarchies and Markets. The Logic and Limits of Network Forms of Organization. Oxford: OUP, 2003.

Ubiqus Reporting. BBC Royal Charter Review: An Analysis of Responses to the DCMS, 2004.Consultation. At

http://www.bbccharterreview.org.uk/pdf_documents/ubiques_analysis_bbccr_respons es.pdf on 26.2.2006.

Ubiqus Reporting. BBC Royal Charter Review. Green Paper Public Consultation. An Analysis of Responses to the DCMS, 2005. Consultation. At http://www.bbccharterreview.org.uk/pdf_documents/ur_analysis\%20of\%20gprespons es.pdf on 20.4.2006

WARNOCK, M. Accountability, Responsibility - or Both? Independent Broadcasting 2, November 1974: 2-3. 